University of South Carolina

Scholar Commons

1990

\title{
Electrochemical Behavior of Graphite and Ni-Cr Electrodes in Sodium Polysulfide in the Absence and Presence of Hydrogen Sulfide
}

Z. Mao

Texas A \& M University - College Station

Ralph E. White

University of South Carolina - Columbia, white@cec.sc.edu

B. Dandapani

Texas A \& M University - College Station

A. Anani

Texas A \& M University - College Station

S. Srinivasan

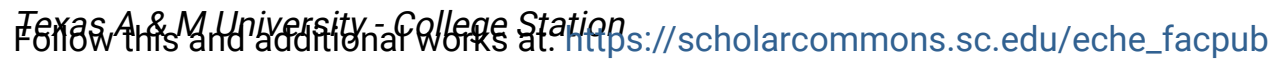

Part of the Chemical Engineering Commons

See next page for additional authors

Publication Info

Journal of the Electrochemical Society, 1990, pages 2189-2194.

(C) The Electrochemical Society, Inc. 1990. All rights reserved. Except as provided under U.S. copyright law, this work may not be reproduced, resold, distributed, or modified without the express permission of The Electrochemical Society (ECS). The archival version of this work was published in the Journal of the Electrochemical Society.

http://www.electrochem.org/

DOI: $10.1149 / 1.2086909$

http://dx.doi.org/10.1149/1.2086909

This Article is brought to you by the Chemical Engineering, Department of at Scholar Commons. It has been accepted for inclusion in Faculty Publications by an authorized administrator of Scholar Commons. For more information, please contact digres@mailbox.sc.edu. 


\section{Author(s)}

Z. Mao, Ralph E. White, B. Dandapani, A. Anani, S. Srinivasan, and A. J. Appleby 
$1.4 \times 10^{15}$ to $5.38 \times 10^{11} \Omega \mathrm{cm}$ at $200^{\circ} \mathrm{C}$ with increase in $\mathrm{Na}^{+}$ concentration.

Figure 4 shows the variation in conductivity as a function of reciprocal temperature. Two distinct regions were observed. The activation energy was calculated from these plots. The activation energy decreases with increase in $\mathrm{Na}^{+}$ concentration from 0.37 to $0.2 \mathrm{eV}$ at low temperature and 1.32 to $0.91 \mathrm{eV}$ at higher temperature regions.

Dielectric parameters ( $\epsilon$ and $\tan \delta$ ) were measured from $10^{2}-10^{6} \mathrm{~Hz}$ at $25^{\circ}, 100^{\circ}$, and $200^{\circ} \mathrm{C}$. A decrease in dielectric constant was observed with increase in frequency (Fig. 5 and 6). Dependence of dielectric loss on temperature and frequency is shown in Fig. 7 and 8. By the addition of $\mathrm{Na}^{+}$, loss value increased from 0.16 to 0.8 .

\section{Conclusions}

1. Cyclodehydration of poly(amide-acid) is influenced by the presence of $\mathrm{Na}^{+}$ions. An increase in $\mathrm{Na}^{+}$ion concentration resulted in a decrease in cyclodehydration reaction.

2. The conductivity measurement showed sodium ion participation in conduction.

3. A decrease in resistivity and activation energy is observed with increase of sodium ion concentration.

Manuscript submitted April 10, 1989; revised manuscript received Feb. 1, 1990.

Indian Institute of Technology assisted in meeting the publication costs of this article.

\section{REFERENCES}

1. D. R. Day, D. Ridley, J. Mario, and S. D. Senturia, in "Polyimides: Synthesis, Characterization and Applications," Vol. 2, K. L. Mittal, Editor, p. 767, Plenum Press, New York (1984).

2. A. E. S. Lloyd and J. R. Chin, ibid., p. 889

3. NEC Corporation, Japan Kokai Tokyo Koho JP 59 , 141,242 (1984), cf. CA 102, 54755t (1985).

4. L. Minnema, Z. Vander, and M. Johan, Eur. Pat. Appl., EP 131,992 (1983), cf CA 102, 176539w (1985).

5. G. Samuelson and S. Lytle, in "Polyimides: Synthesis, Characterization and Applications," Vol. 2, K. L. Mittal, Editor, p. 751, Plenum Press, New York (1984).

6. S. Wolf and W. Atwood, U.S. Pat. 4,495,220 (1985), cf. CA. 102,124014b (1985).

7. K. Sato, S. Harada, A. Saiki, T. Kimura, T. Okuba, and K. Mukai, IEEE Trans. Parts, Hybrids Packag. PHP-9, 178 (1973).

8. A. Saiki, S. Harada, T. Okuba, K. Mukai, and T. Kimura, This Journal, 124, 1619 (1977).

9. A. J. Gregoritsch, Reliability Physics Symposium, 14 Annual Proceedings, p. 228 (1976).

10. K. Mukai, A. Saiki, K. Yamanha, S. Harada, and S. Shoji, IEEE J. Solid State Circuits, SC-13-4, 462 (1978).

11. G. A. Brown, ACS Symp. Ser., 184, 151 (1982); and Rel. Phys. 19th Ann. Proc., 282 (1981).

12. I. K. Varma, S. Saxena, A. Tripathi, T. C. Goel, and D. S. Varma, J. Appl. Polym. Sci., 32, 3987 (1986).

13. I. K. Varma, S. Saxena, A. Tripathi, and D. S. Varma, Polym., 29, 559 (1988).

14. W. Schottky, Z. Physik, 15, 872 (1914).

\title{
Electrochemical Behavior of Graphite and $\mathrm{Ni}-\mathrm{Cr}$ Electrodes in Sodium Polysulfide in the Absence and Presence of Hydrogen Sulfide
}

\author{
Z. Mao* and R. E. White ${ }^{\star \star}$ \\ Department of Chemical Engineering, Texas A\&M University, College Station, Texas 77843 \\ B. Dandapani, ${ }^{* \star}$ A. Anani, ${ }^{\star *}$ S. Srinivasan, ${ }^{\star \star}$ and A. J. Appleby ${ }^{\star *}$ \\ Center for Electrochemical Systems and Hydrogen Research, Texas A\&M University, College Station, Texas 77843
}

\begin{abstract}
The electrochemical behavior of graphite and $\mathrm{Ni}-\mathrm{Cr}$ electrodes in sodium tetrasulfide melt has been investigated using voltammetric, chronoamperometric, and chronopotentiometric techniques in the presence and absence of hydrogen sulfide. Two continuous phases, namely, $\mathrm{Na}_{2} \mathrm{~S}_{2}$ and $\mathrm{Na}_{2} \mathrm{~S}$, are apparently formed at different potentials during the cathodic polarization. The blocking effect by these layers was much less significant on the Ni-Cr electrode than on graphite. The presence of $\mathrm{H}_{2} \mathrm{~S}$ did not appear to influence the electrode reactions, but it significantly reduced the rate of formation of the continuous phases $\left(\mathrm{Na}_{2} \mathrm{~S}_{2}\right.$ or $\left.\mathrm{Na}_{2} \mathrm{~S}\right)$ during cathodic polarization. A small amount of hydrogen gas was formed, possibly by chemical reactions between polysulfides and hydrogen sulfide.
\end{abstract}

There are severe environmental restraints on hydrogen sulfide emissions. The Claus process is presently used to produce sulfur from hydrogen sulfide recovered from natural gas and oil. However, this process has several shortcomings, in particular, hydrogen is lost in the process as steam. Alternative methods that produce sulfur and hydrogen simultaneously have been proposed, including thermodecomposition and electrolysis. Electrochemical methods may be more flexible and more economically feasible than thermodecomposition because elemental sulfur and pure hydrogen gas can then be obtained in a simple process. However, electrolysis both at low temperatures

* Electrochemical Society Student Member.

** Electrochemical Society Active Member. $\left(<100^{\circ} \mathrm{C}\right)$ in aqueous solutions (1-3) and at high temperatures $\left(>600^{\circ} \mathrm{C}\right)(4)$ in molten salts has been shown to have practical difficulties. For example, in aqueous solution, the electrode is likely to become blocked by the sulfur produced, which may require the addition of organic solvents to the electrolyte $(1,2)$. Consequently, additional steps (drying, extraction, and purification) could be required to collect sulfur. At high temperatures $\left(>600^{\circ} \mathrm{C}\right)$, electrode materials become a serious problem, the solubility of hydrogen sulfide in high-temperature melt may be very low and the $\mathrm{H}_{2} \mathrm{~S}$ removal efficiency may be inefficient because of its low solubility in the melt. However, the use of a medium temperature molten salt $\left(200^{\circ}-600^{\circ} \mathrm{C}\right)$ may overcome the shortcomings of electrolysis both at low $\left(<100^{\circ} \mathrm{C}\right)$ and 
at high $\left(>600^{\circ} \mathrm{C}\right)$ temperature. Bartlett et al. (5) have proposed the use of molten NaHS in this application. The sulfur literature $(6,7)$ shows that in systems where sulfur and sulfide co-exist, species exist in form $\mathrm{S}_{x}$ or $\mathrm{S}_{x}{ }^{2-}$, where $x$ varies from 2 to 10 or even higher, depending on temperature and the medium: thus, formation of polysulfide is inevitable in any process for sulfur production from hydrogen sulfide. Since sodium polysulfides have relatively low melting points (below $400^{\circ} \mathrm{C}$ ), and the following reaction may be possible

$$
\mathrm{Na}_{2} \mathrm{~S}_{x}+\mathrm{H}_{2} \mathrm{~S} \rightleftharpoons \mathrm{NaHS}_{x}+\mathrm{NaHS}
$$

which may result in high effective solubility of $\mathrm{H}_{2} \mathrm{~S}$ in the melt. Hence, sodium polysulfide melt may serve as a more effective electrolyte than $\mathrm{NaHS}$. If this melt has the correct properties, its use in an electrolyzer with a structure similar to that of the molten carbonate fuel cell should result in a simple process for the recovery of both elemental sulfur and gaseous hydrogen from hydrogen sulfide. Until the present time, there is no data on the effective solubility of hydrogen sulfide in this melt and on the corresponding kinetics of the hydrogen evolution. This investigation was conducted to determine the suitability of sodium polysulfide melt as electrolyte for the decomposition of $\mathrm{H}_{2} \mathrm{~S}$. For this purpose, the electrochemical behavior of graphite and $\mathrm{Ni}-\mathrm{Cr}$ electrodes in this melt in the presence and absence of $\mathrm{H}_{2} \mathrm{~S}$ was investigated using voltammetric, chronoamperometric, and chronopotentiometric techniques.

\section{Experimental}

Sodium tetrasulfide (Alfa Ventron) was used in the experiments without further purification. The counterelectrode was a graphite rod; the working electrode was either a graphite rod or a $\mathrm{Ni}-\mathrm{Cr}$ alloy $(90 \% \mathrm{Ni}, 10 \% \mathrm{Cr})$ plate. When the graphite rod was used as the working electrode, only the flat bottom surface of the electrode was exposed to the electrolyte, the rest of the electrode being sealed with a high-temperature cement. The Ni-Cr electrode was spot welded with pure nickel wire for electrical contact, all except the reaction zone being sealed with the same cement.

Figure 1 shows a schematic view of the experimental Pyrex glass cell. The reference graphite electrode was in a compartment separated by a glass frit, as shown in Fig. Ib. This reference electrode compartment was partially filled with pure sulfur before being introduced into the cell, which resulted in the entry of some melt from the main cell through the fritted glass. A stable potential of the reference electrode was achieved, since the electrode potential of the $\mathrm{Na}_{2} \mathrm{~S}_{x} / \mathrm{S}$ couple $(x>5)$ is independent of composition $(8,9)$, and the composition at the interface between the sodium polysulfide (lower part) and the sulfur (top part) is constant. All potentials given are relative to this reference electrode.

A home-made furnace was used to melt the electrolyte and to maintain cell temperature. PAR Model 273 poten-

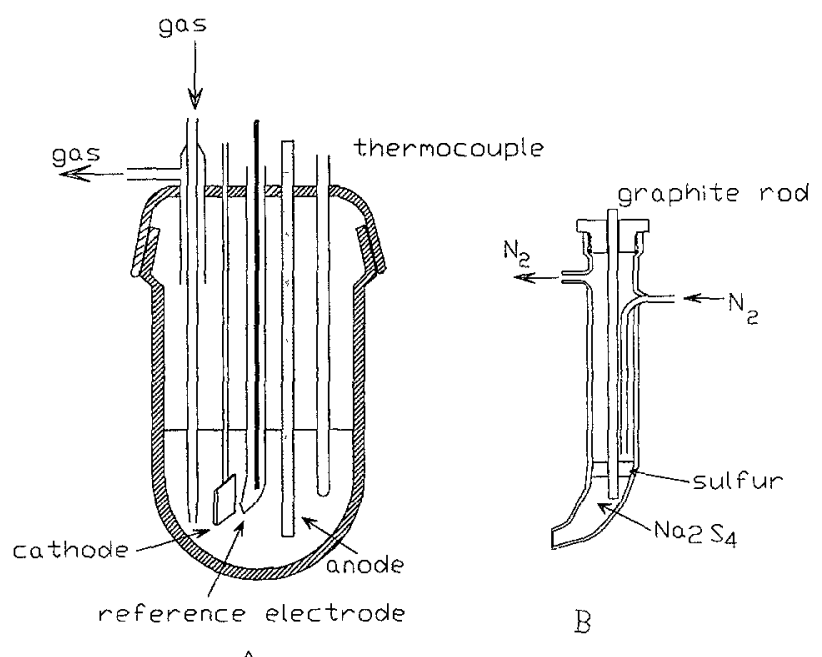

Fig. 1A. Schematic of the experimental cell, B reference electrode

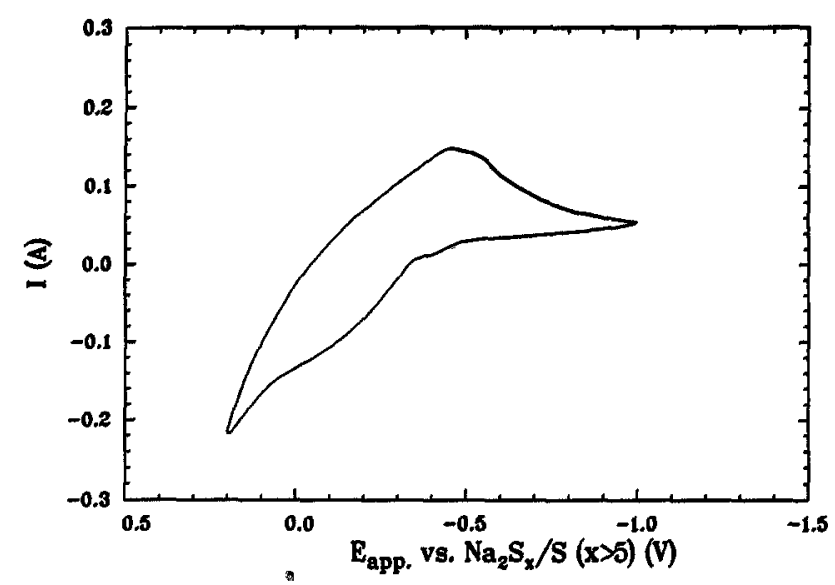

Fig. 2. A typical cyclic voltammogram at the graphite electrode with $\mathrm{N}_{2}$ bubbling; the electrode area $0.28 \mathrm{~cm}^{2}$, temperoture $320^{\circ} \mathrm{C}$, scan rate $2 \mathrm{mV} / \mathrm{s}$.

tiostat/galvanostat coupled with an IBM PS2A system was used for the electrochemical studies.

\section{Results and Discussion}

Voltammetry.-Figures 2 and 3 show the typical voltammograms of the sodium tetrasulfide at the graphite and at the $\mathrm{Ni}$-Cr electrodes, respectively, at $320^{\circ} \mathrm{C}$ in a nitrogen atmosphere. When the ohmic resistance between the working electrode and reference electrode was corrected, the potential at the peak current was almost independent of the scan rate, and was about $-0.31 \mathrm{~V}$ at the graphite electrode and about $-0.35 \mathrm{~V}$ at the $\mathrm{Ni}$-Cr electrode.

The voltammetric experiments were repeated with mixtures of $10 \% \mathrm{H}_{2} \mathrm{~S}$ and $90 \% \mathrm{H}_{2}$ and $10 \% \mathrm{H}_{2} \mathrm{~S}$ and $90 \% \mathrm{~N}_{2}$ bubbling through the melt. Experiments were carried out after the gas mixture had been bubbled through the melt for about $2 \mathrm{~h}$. The voltammograms obtained in this experiment were identical to those with pure $\mathrm{N}_{2}$ bubbling through the melt. The voltammograms obtained here were similar to those at relatively high scan rates $(10-12)$, where the peak current may be reasonably attributed to mass transport limitations. However, in the present work, a distinct peak current which varied linearly with the square root of the scan rate was still observed even at the scan rate of $0.5 \mathrm{mV} / \mathrm{s}$ on the graphite electrode. This peak current occurring at a low scan rate is more likely due to the formation of a blocking layer than due to diffusion of reactants since the current interruption after the peak current revealed a potential plateau at about $-0.285 \mathrm{~V}$, indicating the presence of two phases at the electrode-electrolyte interface. Supporting evidence for blocking was the smaller current observed in the second potential sweep and the shift of the potential in the negative direction. The equilibrium potential of $\mathrm{S}_{3}{ }^{2-} / \mathrm{S}_{2}{ }^{2-}$ is $-0.295 \mathrm{~V}$ and that of $\mathrm{S}_{4}{ }^{2-} / \mathrm{S}_{2}{ }^{2-}$ is

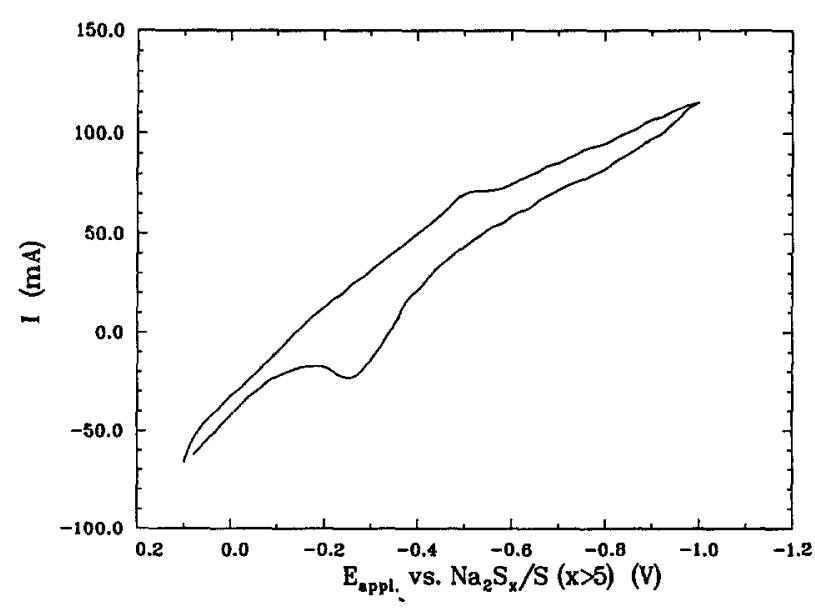

Fig. 3. A typical cyclic voltammogram at the $\mathrm{Ni}-\mathrm{Cr}$ electrode with $\mathrm{N}_{2}$ bubbling; the electrode area $0.32 \mathrm{~cm}^{2}$, the scan rate $5 \mathrm{mV} / \mathrm{s}$, temperature $320^{\circ} \mathrm{C}$. 


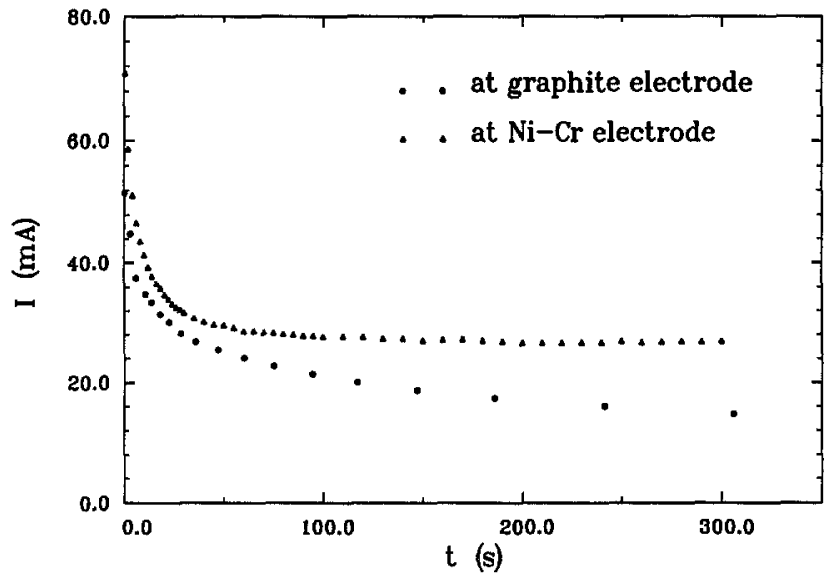

Fig. 4. Total current vs. time; $(\Theta)$ graphite electrode, electrode orea $0.28 \mathrm{~cm}^{2}, E_{\text {app }}=-0.315 \mathrm{~V}$ vs. $\mathrm{Na}_{2} \mathrm{~S}_{x} / \mathrm{S}(x>5),(\Delta)$ the $\mathrm{Ni}-\mathrm{Cr}$ electrode, electrode area $0.32 \mathrm{~cm}^{2}, E_{\text {opp }}=-0.3 \vee$ vs. $\mathrm{Na}_{2} S_{\mathrm{x}} / S(x>5)$.

$-0.241 \mathrm{~V}$ at $320^{\circ} \mathrm{C}(12)$. Therefore, the composition of the melt at the interface between the melt and the electrode may consist of $\mathrm{Na}_{2} \mathrm{~S}_{4}$ and $\mathrm{Na}_{2} \mathrm{~S}_{2}$.

At the $\mathrm{Ni}-\mathrm{Cr}$ electrode, a plateau instead of a peak like the one in Fig. 2 appeared on the voltammogram, and the current continued to increase after the plateau. The height of the plateau increased and became a peak as the scan rate of potential increased. These features of the voltammograms indicate that in contrast with graphite the $\mathrm{Ni}-\mathrm{Cr}$ electrode surface was not blocked by the layer of the reaction product, the plateau current being apparently limited by reactant diffusion through a thin layer on or near the surface. If this thin layer is related to the accumulation of the reaction product, it should be thinner at a high potential scan rate, yielding a more rapid reactant diffusion rate. It therefore appears that the reaction product is not strongly retained on the $\mathrm{Ni}-\mathrm{Cr}$ electrode surface, but remains in its vicinity. Current interruption experiments did not show a potential decay curve plateau, as on the graphite electrode, which indirectly suggests that a blocking layer does not form in this case. It was observed that a much longer time for potential recovery at the graphite electrode was required compared with that of the $\mathrm{Ni}-\mathrm{Cr}$ electrode. This transition time should serve as an indicator of the different processes during potential recovery: a phase transition occurs at the graphite electrode, whereas recovery of the concentration of the electroactive species by diffusion and chemical reactions takes place near the Ni-Cr electrode surface.

Because the electrode reactions for the polysulfide melt species themselves are rapid, the voltammetric pattern

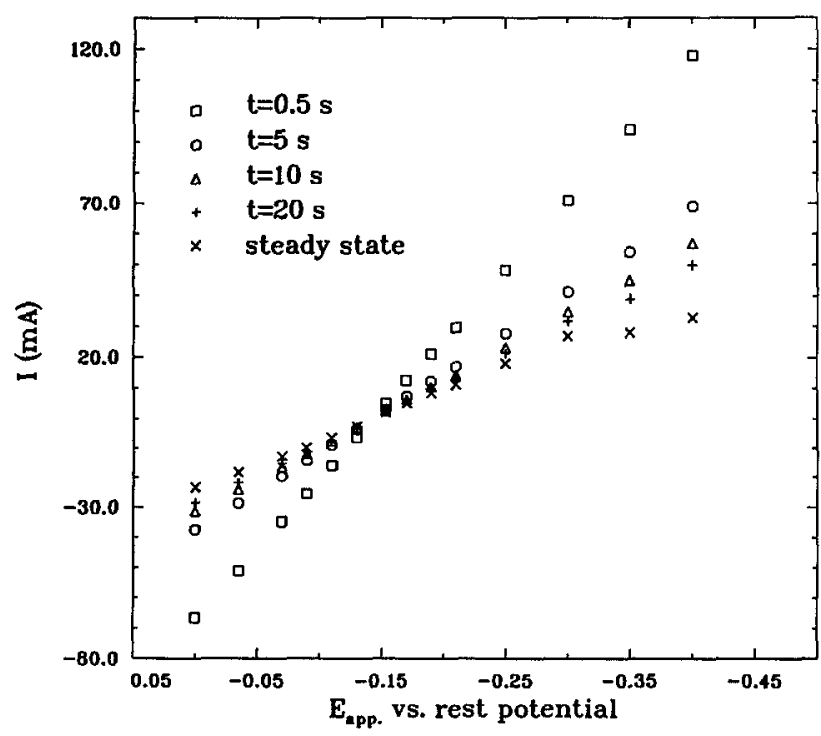

Fig. 5. Polarization curves at different time at the $\mathrm{Ni}-\mathrm{Cr}$ electrode with $\mathrm{N}_{2}$ bubbling, the electrode area $0.32 \mathrm{~cm}^{2}$, temperature $320^{\circ} \mathrm{C}$.

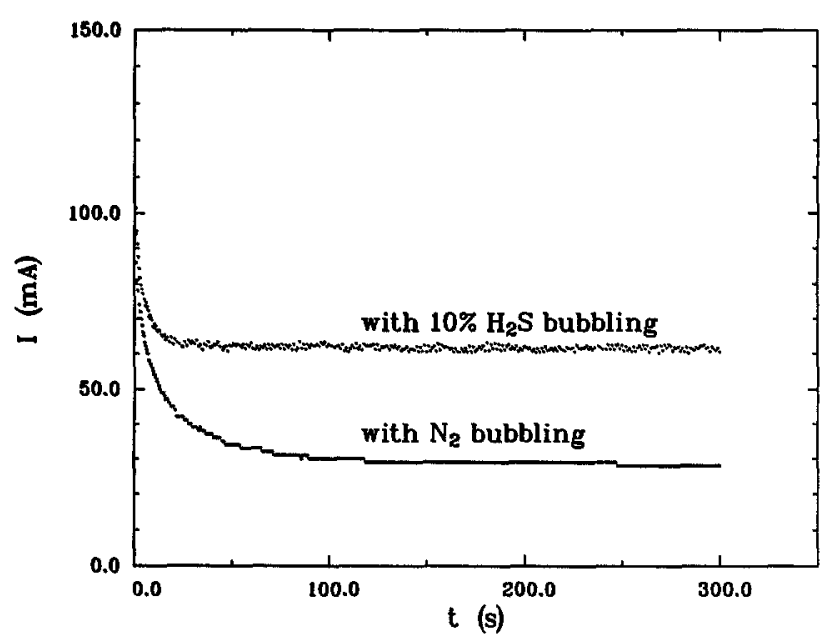

Fig. 6. Typical chronoamperometric curves at the $\mathrm{Ni}-\mathrm{Cr}$ electrode, the electrode area $0.32 \mathrm{~cm}^{2}, E_{\text {app }}=-0.35 \mathrm{~V} v \mathrm{~s} . \mathrm{Na}_{2} \mathrm{~S}_{\mathrm{x}} / \mathrm{S}(\mathrm{x}>5)$, temperature $320^{\circ} \mathrm{C}$.

may be completely controlled by the ohmic resistance in the bulk and on the electrode surface. Under such conditions, the effect of $\mathrm{H}_{2} \mathrm{~S}$ on the voltammograms may be insignificant, even though there will be a great tendency for formation of $\mathrm{NaHS}$ from $\mathrm{H}_{2} \mathrm{~S}$ and $\mathrm{Na}_{2} \mathrm{~S}_{x}$. It was observed that the open-circuit potential shifted in the positive direction when a mixture of $\mathrm{H}_{2} \mathrm{~S}$ and $\mathrm{N}_{2}$ gases was bubbled through the melt. The total potential shift depended on the composition of the gas mixture, about $15 \mathrm{mV}$ for $10 \% \mathrm{H}_{2} \mathrm{~S}$ mixture and $30 \mathrm{mV}$ for $50 \% \mathrm{H}_{2} \mathrm{~S}$ mixture. This phenomenon may result from chemical reactions which generate zero-valent sulfur in the form of a higher polysulfide, for example

$$
\mathrm{Na}_{2} \mathrm{~S}_{x}+\mathrm{H}_{2} \mathrm{~S} \rightleftharpoons \mathrm{Na}_{2} \mathrm{~S}_{x+1}+\mathrm{H}_{2}
$$

The free energy change for the above reaction is less than $20 \mathrm{~kJ} / \mathrm{mol}(11,13)$, and it becomes smaller as the polysulfide chain length decreases.

Chronoamperometry.-Figure 4 shows typical chronoamperometric curves at the graphite and $\mathrm{Ni}-\mathrm{Cr}$ electrodes in a nitrogen atmosphere. The steady state was reached at the $\mathrm{Ni}-\mathrm{Cr}$ electrode within about $25 \mathrm{~s}$, whereas the current continuously decreased even after 300 s at the graphite electrode. A plot of the current $v s$. potential at a fixed time at the $\mathrm{Ni}-\mathrm{Cr}$ electrode was linear, and its slope decreased gradually with time as shown in Fig. 5.

The influence of $\mathrm{H}_{2} \mathrm{~S}$ on the chronoamperometric results is shown in Fig. 6 . The transient time became shorter when $\mathrm{H}_{2} \mathrm{~S}$ gas was bubbled through the melt, where the steadystate current was higher than when $\mathrm{N}_{2}$ was passed through the melt. The polarization curves at zero time and at the steady state are shown in Fig. 7a and b. The current is slightly higher with $\mathrm{H}_{2} \mathrm{~S}$ bubbling than with $\mathrm{N}_{2}$ at the same potential other than at the same overpotential as shown in Fig. 7a. However, the current at steady state doubled when $\mathrm{H}_{2} \mathrm{~S}$ was bubbled through the melt as shown in Fig. 7b.

On current interruption at a potential more negative than $-400 \mathrm{mV}$, the potential fell initially to a plateau at about $-0.285 \mathrm{~V}$ before a further potential decay at the graphite electrode occurred. The plateau was longer at higher applied potentials. In contrast, after current interruption, the open-circuit potential continuously decreased with time at $\mathrm{Ni}-\mathrm{Cr}$. In addition, the potential recovery time was much longer at the graphite electrode than at $\mathrm{Ni}-\mathrm{Cr}$. With $\mathrm{H}_{2} \mathrm{~S}$ bubbling, both plateau length and potential recovery time were reduced.

The decrease in current with time shown in the chronoamperometric curves may result from two factors, namely, increasing resistance of the electrode surface and consumption of the reactant. As shown in Fig. 5 , there is a linear relation between current and potential or overpotential, i.e., $i=k(t) \eta$, where $k(t)$ is only a function of time, and $\eta$ is the overpotential; the quantity $k(t)$ can be considered to be the conductivity at time $t$, and its reciprocal repre- 

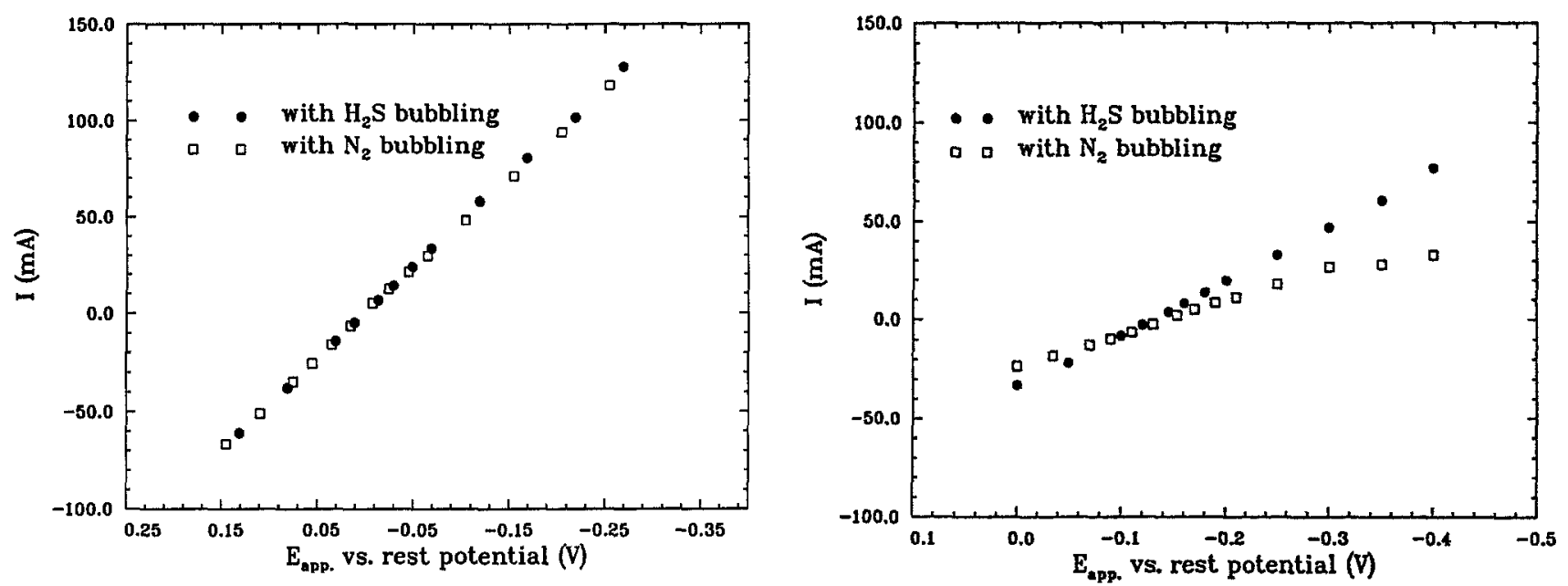

Fig. 7. Polarization curves ot the Ni-Cr electrode the electrode area $0.32 \mathrm{~cm}^{2}$, temperature $320^{\circ} \mathrm{C}$. (a, left) At the initial time $(t=0.5 \mathrm{~s})$; (b, right) at steady state.

sents resistance at time $t$. Figure 8 representing the dependence of resistance on time indicates a sharp increase, which was always lower with $\mathrm{H}_{2} \mathrm{~S}$ bubbling compared with $\mathrm{N}_{2}$ bubbling. If increase in this resistance with time is due to accumulation of product and depletion of reactant, it is expected that the resistance could be proportional to the accumulation of the reaction product near the electrode, i.e., to the integral of the current at time $t$ minus that at steady state. In other words, the following equation should hold

$$
R(t)=\frac{1}{k(t)}=a(\eta)+b(\eta) \int_{0}^{t}\left|i(t, \eta)-i_{\infty}(\eta)\right| d t
$$

where $i(t, \eta)$ is the current at time $t$ and overpotential $\eta$, $i_{\infty}(\eta)$ is the current at steady state and overpotential $\eta$.

Figure 9 shows this relationship. For a certain value of

$\int_{0}^{t}\left|i(t, \eta)-i_{\infty}(\eta)\right| d t$, the resistance is slightly higher with

$\mathrm{H}_{2} \mathrm{~S}$ gas bubbling than that with $\mathrm{N}_{2}$ bubbling. The features of these curves indicate that the presence of $\mathrm{H}_{2} \mathrm{~S}$ does not affect the resistance, but prevents the resistance from continuously increasing. However, it could not be excluded that a portion of the current was used for hydrogen reduction when $\mathrm{H}_{2} \mathrm{~S}$ was present. Analysis of the exit gas by gas chromatography showed that only a small amount of hydrogen was produced from the cell. The quantity of the produced hydrogen was much less than that expected from the difference in Fig. 7b. Therefore, electroreduction of hydrogen sulfide may not be the cause for the large $\mathrm{H}_{2} \mathrm{~S}$ current in the chronoamperometric experiments, which may result from thinner resistance layer near the electrode.

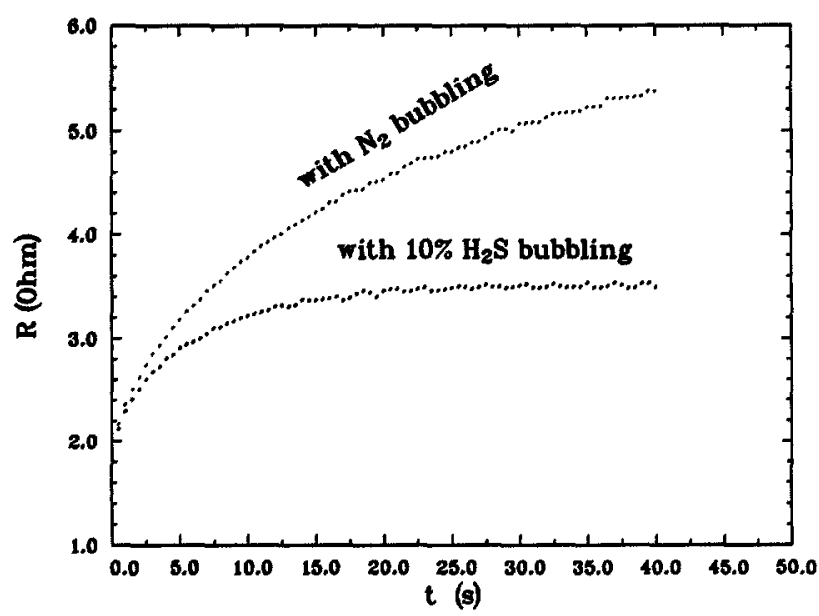

Fig. 8. Relationship between resistance and time at the $\mathrm{Ni}-\mathrm{Cr}$ electrode, electrode area $0.32 \mathrm{~cm}^{2}$, temperature $320^{\circ} \mathrm{C}$.
Chronopotentiometry.-The current at steady state represents the reaction rate of a chemical reaction between the reaction product and the bulk electrolyte, or of the mass transport rate from the surface to the bulk or vice versa. A higher current at a steady state corresponds to a higher exchange rate between the product of the electrode reaction and the melt. The chronopotentiometric technique can identify reactions at the electrodes and trans-

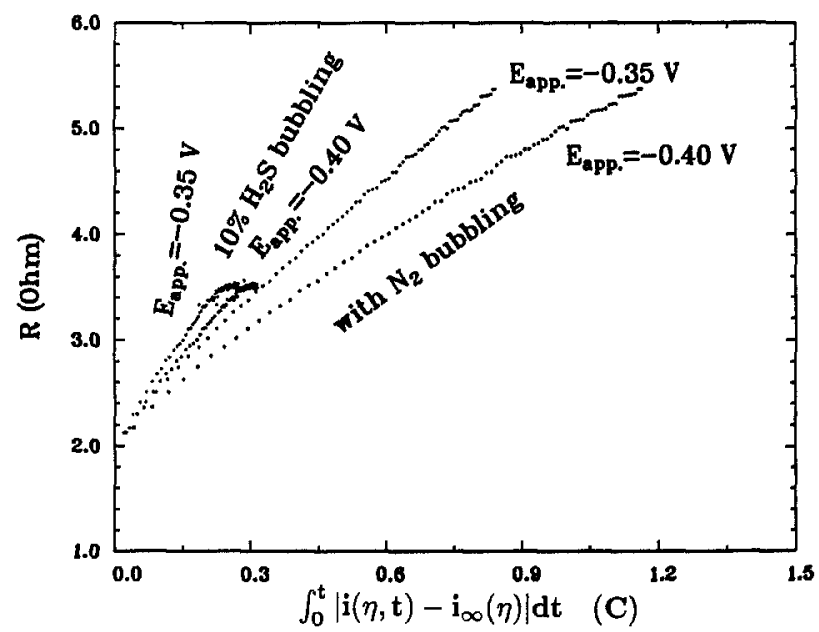

Fig. 9. The relationship between resistance and the integral of the current at the present time minus the current at the steady state, the $\mathrm{Ni}-\mathrm{Cr}$ electrode, the electrode area $0.32 \mathrm{~cm}^{2}$, temperature $320^{\circ} \mathrm{C}$.

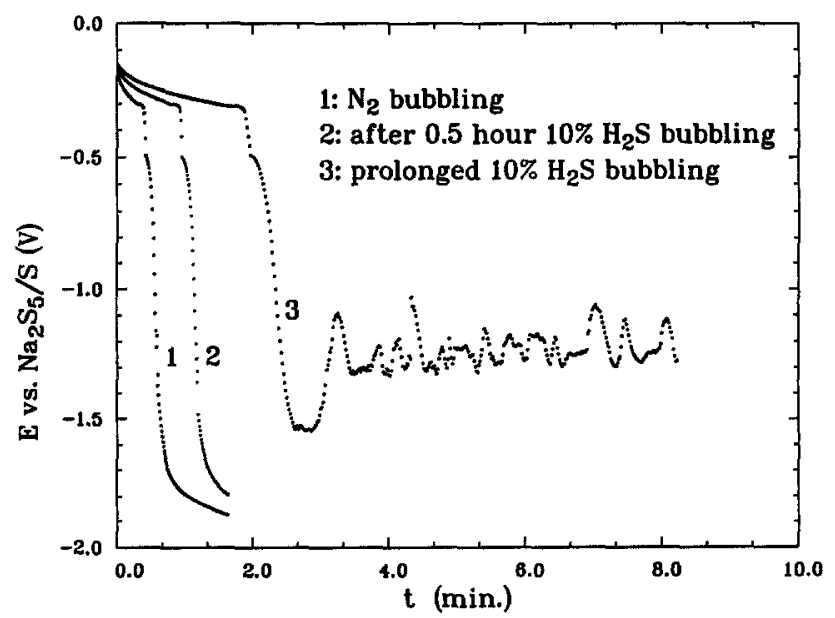

Fig. 10. Cathodic chronopotentiometric curves at graphite electrode temperature $300^{\circ} \mathrm{C}, I_{\text {app }}=5 \mathrm{~mA}$, electrode area $0.071 \mathrm{~cm}^{2}$; curve 1 , $\mathrm{N}_{2}$ bubbling; curve 2, after $0.5 \mathrm{~h}$ of $\mathrm{H}_{2} \mathrm{~S}$ bubbling; curve 3 , after $1 \mathrm{~h}$ or longer of $\mathrm{H}_{2} \mathrm{~S}$ bubbling. 

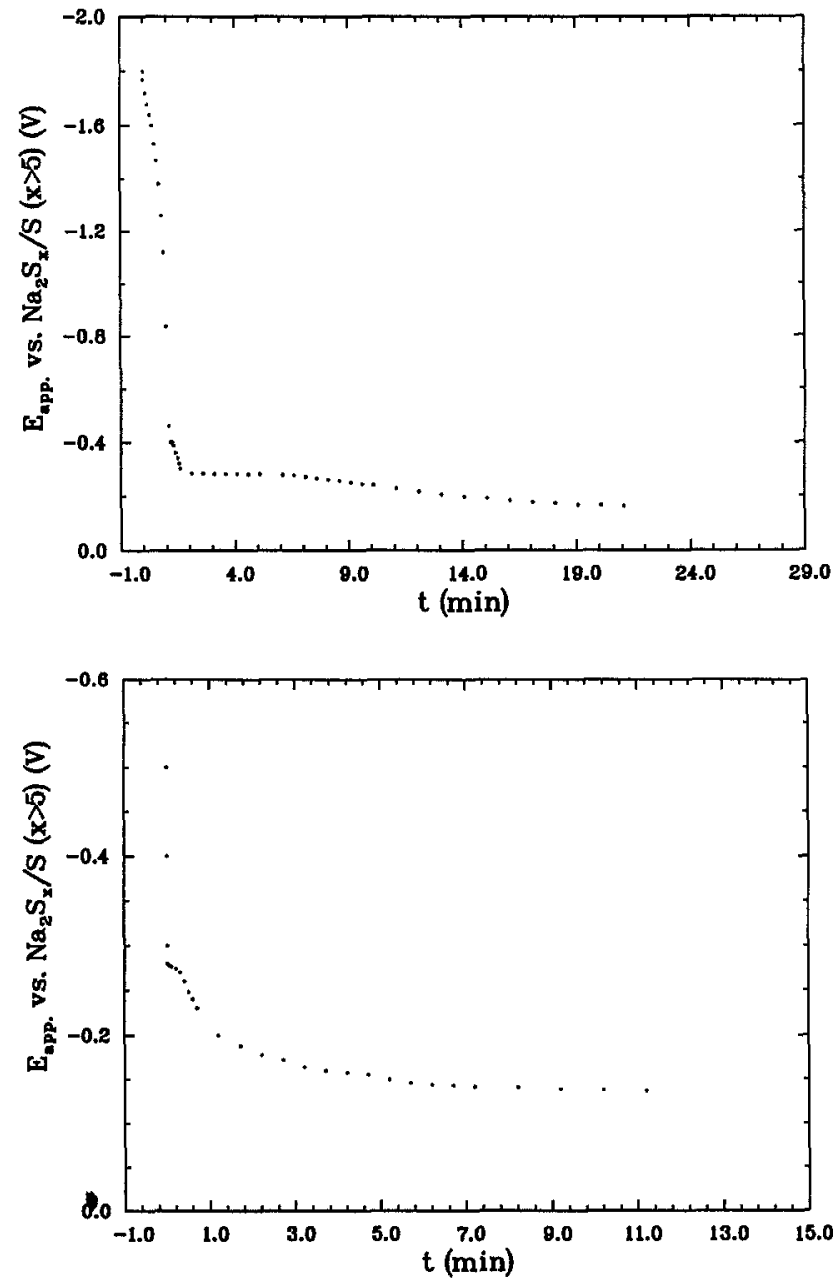

port hindrances, because the reaction rate is here externally controlled.

Figure 10 shows typical cathodic chronopotentiometric patterns. Two flat segments and two sharp decreases in potential with time occurred when pure nitrogen gas or a mixture of $\mathrm{H}_{2} \mathrm{~S}$ and nitrogen gases was bubbled through the melt. The first transition time increases when a gas containing $\mathrm{H}_{2} \mathrm{~S}$ was used. The second plateau occurs at the same potential, and is independent of the gas composition. When the experiment was carried out after $\mathrm{H}_{2} \mathrm{~S}$ bubbling for $1 \mathrm{~h}$ or longer, the potential oscillated after the second plateau occurred. The following processes may take place during the cathodic polarization at a constant current. Within the first pleateau, higher polysulfide species are reduced to a lower polysulfide species. Gradual accumulation of the resulting species near the electrode surface will finally form a continuous film, resulting in a sharp rise in the potential. However, the species in this phase is not a solid film and is reducible at more negative potentials. As the potential reaches the values where reduction occurs, another plateau appears. The product formed in the second plateau may form a continuous film, causing another sharp rise in potential. The presence of $\mathrm{H}_{2} \mathrm{~S}$ delayed the formation of these continuous films near the electrode surface.

Figure 11 shows potential decay curves after the currents were interrupted. As expected, two potential plateaus appear on this curve, at about $-0.28 \mathrm{~V}$ and at about $-0.4 \mathrm{~V}$, respectively. The short plateau at $-0.4 \mathrm{~V}$ shows that the film is very thin, which may indicate that the electrolyte can react with the reaction product and remove it from the surface, so that the film never becomes very thick. The equilibrium potential of the redox couple $\mathrm{Na}_{2} \mathrm{~S}_{4} / \mathrm{Na}_{2} \mathrm{~S}$ is $-0.35 \mathrm{~V}$ (12). Activation and concentration overpotentials may cause the potential to shift about $50 \mathrm{mV}$ in the cathodic direction. Therefore, the two phases may be $\mathrm{Na}_{2} \mathrm{~S}_{2}$ at $-0.28 \mathrm{~V}$ and $\mathrm{Na}_{2} \mathrm{~S}$ at $-0.4 \mathrm{~V}$, respectively. The latter is probably in a solid state because here the potential in creased greatly.

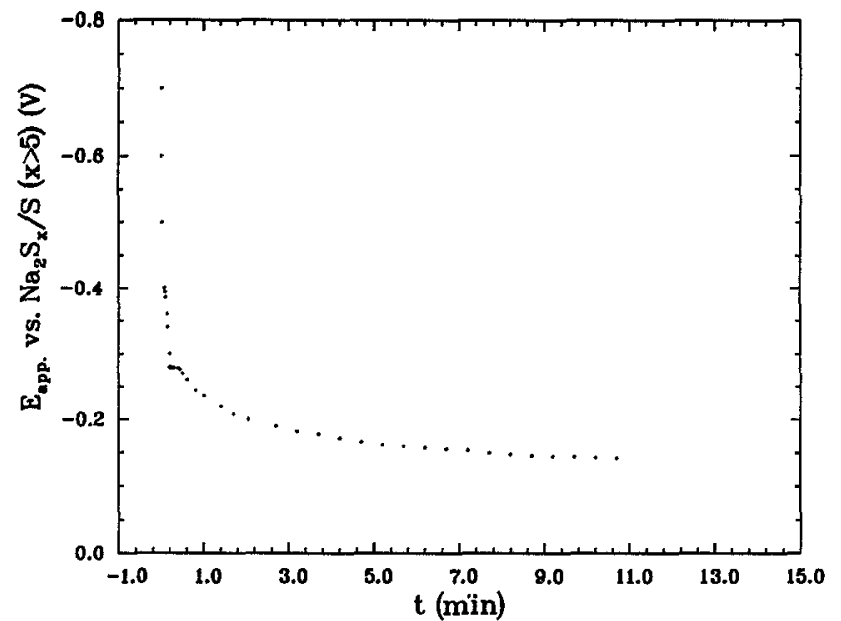

Fig. 11. Potential decay curves after cathodic polarization, (a, top left) after the polarization corresponding to curve 1 in Fig. 10; (b, above) after the polarization corresponding to curve 2 in Fig. 10; (c, left) after the polarization corresponding to curve 3 to Fig. 10 .

The identical shapes of the curves in Fig. 10 indicates that the reaction mechanism did not change when $\mathrm{H}_{2} \mathrm{~S}$ gas was bubbled through the melt; however, the change in transition time suggests that mass transport has been enhanced. This may be due to the removal of the product of reactions of sodium polysulfide near the surface through chemical reactions, such as reaction [1] and the following

$$
\mathrm{Na}_{2} \mathrm{~S}_{2}+\mathrm{H}_{2} \mathrm{~S} \rightleftharpoons \mathrm{NaHS}_{2}+\mathrm{NaHS}
$$

When $\mathrm{Na}_{2} \mathrm{~S}$ is formed, removal of $\mathrm{Na}_{2} \mathrm{~S}$ may involve the following reactions

$$
\begin{gathered}
\mathrm{Na}_{2} \mathrm{~S}+\mathrm{H}_{2} \mathrm{~S} \rightleftharpoons 2 \mathrm{NaHS} \\
\mathrm{Na}_{2} \mathrm{~S}+\mathrm{H}_{2} \mathrm{~S} \rightleftharpoons \mathrm{Na}_{2} \mathrm{~S}_{2}+\mathrm{H}_{2}
\end{gathered}
$$

The potential oscillation after the second potential plateau may then result from continuous removal of $\mathrm{Na}_{2} \mathrm{~S}$ from the surface. Figure 11 shows that the plateau at $-0.4 \mathrm{~V}$ becomes shorter, and even disappears when the containing gas $\mathrm{H}_{2} \mathrm{~S}$ was bubbled through the melt.

\section{Conclusions}

The electrochemical behavior of sodium tetrasulfide melt at graphite and the $\mathrm{Ni}-\mathrm{Cr}$ electrodes in the presence of hydrogen sulfide is complicated, and has not been fully elucidated. However, the following conclusions were derived within the limit of the experiments performed in this work: two continuous phases on the electrodes, apparently $\mathrm{Na}_{2} \mathrm{~S}_{2}$ and $\mathrm{Na}_{2} \mathrm{~S}$, formed at -0.28 and $-0.4 \mathrm{~V} v s$. $\mathrm{Na}_{2} \mathrm{~S}_{5} /$ $S$ during the cathodic polarization. However, the blocking effect by these layers on the $\mathrm{Ni}-\mathrm{Cr}$ electrode was much less significant than on graphite. The presence of $\mathrm{H}_{2} \mathrm{~S}$ did not influence the reactions occurring at the electrodes, but significantly reduced the formation rate of continuous phases (either $\mathrm{Na}_{2} \mathrm{~S}_{2}$ or $\mathrm{Na}_{2} \mathrm{~S}$ ) during cathodic polarization. The effect of $\mathrm{H}_{2} \mathrm{~S}$ on the formation of these films may be due to chemical processes such as reaction [1] and [2] occurring near the electrodes. A small amount of hydrogen gas was 
formed at these potentials, possibly by a chemical reaction between polysulfides and hydrogen sulfide.

Manuscript submitted Feb. 27, 1989; revised manuscript received Jan. 22, 1990 .

Texas A\&M University assisted in meeting the publication costs of this article.

\section{REFERENCES}

1. Y.-S. Lee and J.-L. Lee, Ind. Eng. Chem. Process Des. Dev., 25, 836 (1986)

2. P. W. Bolmer, U.S. Pat. 3,409,520 (1968).

3. D. W. Kalina and E. T. Maas, Jr., Int. J. Hydrogen Energy, 10, 163 (1985).

4. H. S. Lim and J. Winnik, This Journal, 131, 562 (1984).

5. R. W. Bartlett, D. Cubicciotti, D. L. Hildenbrand, D. D MacDonald, K. Semran, and M. E. D. Raymond, SRI Project No. 8030 (July 1979).
6. V. E. Kaloidas and N. G. Papayannakas, Int. J. Hydrogen Energy, 12, 403 (1987).

7. A. V. Tobolsky, "The Chemistry of Sulfides," Interscience, New York (1968).

8. N. K. Gupta and R. P. Tischer, This Journal, 119, 1033 (1972).

9. B. Cleaver and A. J. Davies, Electrochim. Acta, 18, 733 (1973).

10. R. P. Tischer and F. A. Ludwig, in "Advances in Electrochemistry and Electrochemical Engineerings," Vol. 10, P. Delahay and C. Tobias, Editors, John Wiley \& Sons, Inc., New York (1977).

11. D. A. Aikens, in "The Sulfur Electrode", R. P. Tischer, Editor, pp. 178-181, Academic Press, Inc., New York (1983).

12. J. C. Dobson, F. R. Mclarnon, and E. J. Cains, This Journal, 133, 2069 (1986).

13. "Hydrogen Sulphide: Environmental and Technical Information for Problem Spills," Environmental Protection Service, Ottawa, Ont., Canada (1984).

\title{
Technical Notes
}

\section{The Use of Sodium lon Conducting Glasses in Na/S(IV) Molten Chloroaluminate Electrochemical Cells}

\author{
S. W. Orchard, ' Y. Sato, J.-P. Schoebrechts, and G. Mamantov* \\ Department of Chemistry, The University of Tennessee, Knoxville, Tennessee 37996
}

Rechargeable molten salt cells of the type $\mathrm{Na} / \beta^{\prime \prime}$ alumina/ $\mathrm{SCl}_{3}{ }^{+}$in $\mathrm{AlCl}_{3}-\mathrm{NaCl}$, have previously been studied in our laboratory (1-4). The cells operate typically at $180^{\circ}$ $250^{\circ} \mathrm{C}$, and, when fully charged so that the sulfur is in the +4 oxidation state, have an open-circuit voltage of about $4.3 \mathrm{~V}$. Many cells, with capacities in the range $1-20 \mathrm{~A} \cdot \mathrm{h}$ have been built and tested, and development of the system is in progress.

A number of sodium ion conducting glasses have recently been made and tested by Bloom and co-workers $(5,6)$. These glasses have been used, for example, in conjunction with narrow $\alpha$-alumina tubes as separators in contact with molten sodium, polysulfides, and $\mathrm{AlCl}_{3}-\mathrm{NaCl}$ mixtures $(7,8)$.

The present note reports on studies directed toward the possibility of using these sodium ion conducting glasses as separators in small $\mathrm{Na} / \mathrm{S}(\mathrm{IV})$ molten chloroaluminate cells.

\section{Experimental}

$\mathrm{AlCl}_{3}$ (Fluka, puriss.) was further purified and $\mathrm{NaCl}$ (Mallinckrodt, reagent grade) was dried using standard procedures (9). Sodium metal (Fisher, certified) was filtered through Pyrex wool before use. All transfers and weighing of reagents were carried out in a nitrogen-filled dry box. Cells were sealed, but, as an added precaution, were operated in an atmosphere of argon.

"T-glass" (6) was used as the sodium ion conducting glass in this study. It has a high linear expansion coefficient $\left(15 \times 10^{-6} \mathrm{~K}^{-1}\right.$ as compared to $3.2 \times 10^{-6} \mathrm{~K}^{-1}$ for Pyrex glass), an important consideration in using it for cell fabrication. Two types of cells were used. In cell (a), a circular disk of T-glass (ca. $3 \mathrm{~mm}$ diam, $1 \mathrm{~mm}$ thick) was connected to a short tube of soda glass ( $3 \mathrm{~mm}$ id) via a graded seal made from glass mixtures of intermediate coefficients

* Electrochemical Society Active Member.

1 Permanent address: Department of Chemistry, University of the Witwatersrand, 2001 Johannesburg, South Africa. of expansion. The soda glass was in turn attached to a Pyrex tube via a second graded seal. This assembly was used as the inner compartment in a small Pyrex cell of concentric design similar to previous designs which used tubes of $\beta^{\prime \prime}$-alumina as the inner compartment (1).

In cells of type (b), a T-glass membrane was used to seal one end of a short length of $\alpha$-alumina tubing $(1.6 \mathrm{~mm}$ id, $3.2 \mathrm{~mm}$ od), which then served as the inner compartment of a concentric cell with an outer compartment of Pyrex. Swagelok fittings were used both to seal the open end of the $\alpha$-alumina tube and to couple this tube to the Pyrex outer compartment.

Tungsten wires served as current collectors in both types of cell. The inner compartment generally held the premelted mixture of sulfur, $\mathrm{AlCl}_{3}$, and $\mathrm{NaCl}$, with sulfur being the limiting reagent.

\section{Results}

Prior to the construction of the cells, weight loss tests were performed on the four sodium ion conducting glasses listed in Table $I$ to determine their stability in a melt of $\mathrm{AlCl}_{3}-\mathrm{NaCl}(63: 37$ mole percent $[\mathrm{m} / \mathrm{o}])$. Small single pieces (ca. $100 \mathrm{mg}$ ) of the glasses were sealed in Pyrex tubes containing the $\mathrm{AlCl}_{3}-\mathrm{NaCl}$ mixture, and the tubes were then heated to $205^{\circ}-210^{\circ} \mathrm{C}$. After 14 days, the glasses all showed weight losses of at most $0.7 \%$, which was considered to be

Table I. Composition (mass percent) and resistivities of sodium ion conducting glasses

\begin{tabular}{lcrccc}
\hline Code & $\mathrm{Na}_{2} \mathrm{O}$ & $\mathrm{Al}_{2} \mathrm{O}_{3}$ & $\mathrm{ZrO}_{2}$ & $\mathrm{SiO}_{2}$ & $\begin{array}{c}\text { Resistivity, } \\
\text {-cm at 300 }\end{array}$ \\
\hline $\mathrm{X}$ & 37.2 & 11.4 & - & 51.4 & 484 \\
$\mathrm{R}$ & 41.1 & 6.4 & 4.0 & 48.5 & 130 \\
$\mathrm{~T}$ & 40.7 & 10.8 & 8.3 & 40.2 & 215 \\
$\mathrm{ANL}$ & 42.0 & 8.0 & 5.0 & 45.0 & 221
\end{tabular}

